\title{
Modulating Expression of Endogenous Interleukin 1 Beta in the Acute Phase of the Pilocarpine Model of Epilepsy May Change Animal Survival
}

\author{
V. D. B. Pascoal ${ }^{1,2} \cdot$ R. B. Marchesini ${ }^{1}$ - M. C. P. Athié ${ }^{1}$ - A. H. B. Matos ${ }^{1}$ - F. F. Conte ${ }^{1}$ - T. C. Pereira ${ }^{1,3} \cdot$ R. Secolin ${ }^{1,2}$.

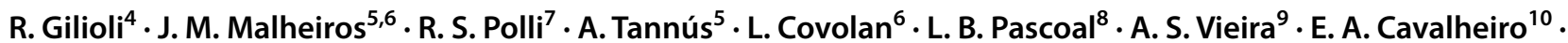 \\ F. Cendes ${ }^{11} \cdot$ I. Lopes-Cendes ${ }^{1}$ iD
}

Received: 4 June 2021 / Accepted: 5 January 2022 / Published online: 21 January 2022

(c) The Author(s) 2022

\begin{abstract}
The pilocarpine-induced (PILO) model has helped elucidate the electrophysiological and molecular aspects related to mesial temporal lobe epilepsy. It has been suggested that the extensive cell death and edema observed in the brains of these animals could be induced by increased inflammatory responses, such as the rapid release of the inflammatory cytokine interleukin 1 beta (Il1b). In this study, we investigate the role of endogenous Il1b in the acute phase of the PILO model. Our aim is twofold. First, we want to determine whether it is feasible to silence Ill b in the central nervous system using a non-invasive procedure. Second, we aim to investigate the effect of silencing endogenous I11b and its antagonist, Il1rn. We used RNA interference applied non-invasively to knockdown $I l l b$ and its endogenous antagonist $I l 1 \mathrm{rn}$. We found that knocking down $I l l b$ prior to pilocarpine injection increased the mortality rate of treated animals. Furthermore, we observed that, when exposing the animals to more Illb by silencing its endogenous antagonist $111 \mathrm{rn}$, there was a better response to status epilepticus with decreased animal mortality in the acute phase of the PILO model. Thus, we show the feasibility of using a novel, less invasive approach to study genes involved in the inflammatory response in the central nervous system. Furthermore, our results provide suggestive evidence that modulating endogenous Illb improves animal survival in the acute phase of the PILO model and may have effects that extend into the chronic phase.
\end{abstract}

Keywords Mesial temporal lobe epilepsy $\cdot$ Neuroinflammation $\cdot$ RNA interference in vivo $\cdot$ Animal model

\section{Introduction}

It has been estimated that nearly half of adult patients with epilepsy have mesial temporal lobe epilepsy (MTLE). Among these, only about $60 \%$ achieve optimal seizure control with clinical treatment, making MTLE one of the most frequent and severe forms of epilepsy (Sander 1993; Mattson 1994; Borges et al. 2004). One approach used to investigate the pathophysiology of MTLE is the study of experimental animal models, which present epileptogenicity similar to that observed in so-called "epileptic" human

V. D. B. Pascoal and R. B. Marchesini have contributed equally to this work.

I. Lopes-Cendes

icendes@unicamp.br

Extended author information available on the last page of the article tissue studied ex vivo. Among the various models available, the pilocarpine-induced (PILO) model is well-established and presents extensive molecular, histological, physiological, and phenomenological characterization (Cavalheiro et al. 1991; Smolders et al. 1997; Hamani et al. 1999; Raza et al. 2001; Garzillo and Mello 2002; Bender et al. 2004; Dudek and Sutula 2007; Curia et al. 2008; Ravizza et al. 2008; Carter et al. 2011; van Eijsden et al. 2011; Mazzuferi et al. 2012; Scharfman and Pierce 2012; Pearson et al. 2014; Gonzalez et al. 2015; Cardim et al. 2016). In addition, the sequence of events observed in the different phases of the PILO model is somewhat similar to that seen in some patients with MTLE in whom an initial precipitating event can be identified (Bender et al. 2004). Furthermore, the histological characteristics of the hippocampal lesion observed in the chronic phase of PILO animals are comparable to that found in patients with MTLE and typical findings of mesial temporal sclerosis (Dudek and Sutula 2007; Curia 
et al. 2008). However, the lesion in the PILO model tends to be more extensive, with spread to extra-hippocampal regions (Fabene et al. 2003; Nairismagi et al. 2004).

It has been well characterized that one important biological phenomenon observed in the acute phase of the PILO model is cell death, which is believed to be caused by apoptosis (Voutsinos-Porche et al. 2004) and necrosis (Malheiros et al. 2014), as well as cell swelling due to massive edema (Ong et al. 2009). Furthermore, it has been suggested that these events could be induced by an inflammatory response (Bernardino et al. 2005; Ravizza et al. 2008). Therefore, changes in the expression of genes related to inflammatory pathways such as interleukins, interferons, tumor necrosis factor (Tnf), and others have been studied in the acute phase of the PILO model (John et al. 2005; Benson et al. 2015; Li et al. 2017). Because of the increased expression of interleukin 1 beta $(I l l b)$ in the acute phase of the PILO model (Voutsinos-Porche et al. 2004), this cytokine has emerged as a candidate key player in the molecular mechanisms underlying the damage induced by pilocarpine. Although a large body of literature has been produced regarding the investigation of Illb in the PILO model (for a review, see Rijkers et al. 2009), there are still many unanswered questions, and the matter is far from resolved (Arzimanoglou et al. 2002). In this study, we investigate the role of endogenous Illb in the acute phase of the PILO model. Our aim is twofold. First, we want to determine whether it is feasible to silence Il $1 \mathrm{~b}$ in the central nervous system using a non-invasive procedure. Second, we aim to investigate the effect of silencing endogenous Il1b and its antagonist, Il1rn. To accomplish these goals, we used a non-invasive and specific tool to modify gene expression-RNA interference (RNAi) — and delivered specially constructed small interfering RNA molecules (siRNA) to inhibit endogenous Ill b and Ill $r n$ in the central nervous system (CNS).

\section{Methods}

\section{Animal Handling}

We used specific-pathogen-free (SPF) 8-week-old male rats (HanUnib:WH) obtained from the Multidisciplinary Centre for Biological Investigation (CEMIB) at the University of Campinas (UNICAMP). The experimental protocols were approved by the Ethics Committee in Animal Experimentation at UNICAMP and were performed in a biosafety level 2 animal facility, following national and international recommendations for the ethical and safe handling of animals. Rats were divided into four groups (five animals per group) as follows: (i) one control group injected with phosphatebuffered saline (PBS), (ii) a second control group injected with an irrelevant siRNA directed against green fluorescent protein (GFP) (siGFP), (iii) an experimental group injected with siRNA directed against $I l l b$ (silllb), and (iv) an experimental group injected with siRNA directed against Illrn (sill1rn). Animals were kept during the experimental period in micro-insulators with sterilized wood shavings in a ventilated rack unit equipped with a HEPA filtration system and with 12-h light/12-h dark photoperiod. Nuvital CR-1 pelleted food and water sterilized by autoclaving were provided ad libitum.

Animals treated with pilocarpine were euthanized at different times for the different experiments, because we analyzed molecular changes occurring in the silent phase 5 days after status epilepticus (SE), and the histological changes occurring in the chronic phase, 90 days after SE.

\section{Peptides and siRNA}

The rabies virus glycoprotein (RVG)-9R peptide (YTIWMPENPRPGTPCDIFTNSRGKRASNGGGGRRRRR RRRR) was synthesized and purified by using high-performance liquid chromatography at the Bio-Synthesis Inc. (Lewisville, TX, USA); the nine C-terminal arginine residues were D-arginine. siRNA were designed against the genes Illb and Illrn using the Strand Analysis program (Pereira et al. 2007). Subsequently, the sequence was checked in the Blast program to confirm that it did not have homology for any other gene expressed in the rat. The siRNA were purchased from IDT (Coralville, IA, USA).

The siRNA sequences are:

sill1b sense: 5' UGACCCAUGUGAGCUGAAAGC 3'; sill1b antisense: 5' UUUCAGCUCACAUGGGUCAGA 3'; sill1rn sense: 5' AGGCACUCCCAGAGUAUGUGU 3'; sill1rn antisense: 5' ACAUACUCUGGGAGUGCCUUC 3'; siGFP sense: 5' CAGGCUACUUGGAGUGUAUUU 3'; siGFP antisense: 5' AUACACUCCAAGUAGCCUGUU 3'.

\section{Delivery of siRNA::Peptide Complexes}

siRNA::peptide complexes (at a molar ratio of 1:10 siRNA to peptide) were delivered through the intravenous (i.v.) route into the lateral tail vein; complexes were prepared in $500 \mu \mathrm{L}$ of PBS containing $5 \%$ glucose. To identify the best experimental conditions (mass of siRNA and number of injections), animals were injected with different amounts of 25-50 $\mu \mathrm{g}$ of siRNA, with one or two injections per animal (with an 8-h interval between injections). Brains were harvested $48 \mathrm{~h}$ after the first injection. To characterize the $I l l b$ silencing time course, rats were given two injections of $25 \mu \mathrm{g}$ of siRNA (with an 8-h interval between injections), and brains were collected at the following time points: $24,48,72,96$, and $120 \mathrm{~h}$ after the first injection of siRNA. To assess the silencing effect in different anatomical areas, the brain was divided into five regions as follows: 
the hippocampus, the frontal cortex, the olfactory bulb, the cerebellum, and the brain stem. The spinal cord was also analyzed (Pascoal 2010).

\section{Real-Time Polymerase Chain Reaction (qPCR)}

To quantify the transcripts of interest, we used three animals per group for each time point. Total RNA was isolated from the brain using the TRIzol reagent (Invitrogen, Carlsbad, CA, USA). RNA was reverse transcribed with SuperScript III and random primers (both from Invitrogen) according to the manufacturer's protocol. qPCR was performed with $40 \mathrm{ng}$ of complementary DNA using the TaqMan System (Applied Biosystems 7500 Real-Time PCR, Foster City, CA, USA). The amplification conditions were as follows: $50{ }^{\circ} \mathrm{C}$ for $2 \mathrm{~min}, 95^{\circ} \mathrm{C}$ for $10 \mathrm{~min}$ followed by 40 cycles of $95^{\circ} \mathrm{C}$ for $15 \mathrm{~s}$ (melting step) and $60^{\circ} \mathrm{C}$ for $1 \mathrm{~min}$ (annealing/extension step).

To assess siRNA specificity, the expression profile of two biologically related genes (Ptgs 2 and $N f k b$ ) and two unrelated genes (Plat and Ntrk2) were determined by using qPCR in all experimental groups. We used Gapdh and Hprtl internal controls for normalization because previous analyses revealed they are the steadiest endogenous controls in the regions analyzed (Tanic et al. 2007). The relative gene expression was calculated by the comparative threshold cycle method (Livak and Schmittgen 2001). All primers and probes were obtained from Applied Biosystems.

\section{Assessment of Blood-Brain Barrier (BBB) Integrity by Magnetic Resonance Imaging}

To determine whether siRNA::RVG-9R promotes BBB lesions, magnetic resonance imaging (MRI) was performed using gadolinium diethylenetriaminepentacetate (GdDTPA) as a paramagnetic contrast. Diffusion of the contrast observed after siRNA::peptide injection would indicate evidence of damage to the BBB (Prior et al. 2004). MRI was performed at the CIERMag on a Bruker electronic (Avance III under Paravision 5) adapted to a 2-Tesla field $31 \mathrm{~cm}$ horizontal superconducting magnet (Oxford Instruments $85310 \mathrm{HR}$, Abingdon, UK). A crossed saddle radiofrequency coil (Papoti et al. 2010) was used as a head probe for the animals. For all animals, the image acquisition started $15 \mathrm{~min}$ after injection of $0.5 \mathrm{M}$ Gd-DTPA $(1 \mathrm{~mL} / \mathrm{kg}$, i.v. $)$ injection. After deep anesthesia, induced by a mixture of ketamine [120 mg/kg, intraperitoneal (i.p.)] and xylazine $(9 \mathrm{mg} / \mathrm{kg}$, i.p.), T1-weighted images were collected using a fast low angle shot (FLASH) sequence. The parameters used were: time of echo (TE) $5.0 \mathrm{~ms}$, repetition time (TR) $200 \mathrm{~ms}$, flip angle $90^{\circ}, 192 \times 192$ points over a field of view of $4 \times 4 \mathrm{~cm}^{2}$, slice thickness $1 \mathrm{~mm}$, interslice gap $1.3 \mathrm{~mm}$, and 16 coronal slices covering almost the entire brain.

\section{Pilocarpine Treatment}

Rats were injected with methylscopolamine $(1 \mathrm{mg} / \mathrm{kg}$ in saline, i.p.; Sigma-Aldrich, St. Louis, MO, USA) $30 \mathrm{~min}$ before injecting pilocarpine hydrochloride $(300 \mathrm{mg} / \mathrm{kg}$ in saline, i.p.; Merck, Quimica, Brazil) to prevent peripheral cholinergic side effects. Immediately after pilocarpine injection, animals were placed in a cage with paper-covered sawdust to avoid choking on sawdust during status epilepticus (SE; status was defined as a condition of continuous seizures lasting longer than $30 \mathrm{~min}$ ). About $40 \mathrm{~min}$ after the pilocarpine injection, approximately $70 \%$ of rats had developed SE consisting of generalized motor seizures, which were interrupted $120 \mathrm{~min}$ after their onset by diazepam administration $(10 \mathrm{mg} / \mathrm{kg}$, i.p.) to reduce the mortality rate. Only rats with seizures that achieved class five motor behavior as described in the Racine Scale as loss of postural tone, jumping, and generalized tonic-clonic activity, and entered SE after pilocarpine injection, were used for subsequent analyses because previous experiments showed that these rats develop spontaneous recurrent seizures in the chronic phase (Turski et al. 1984; Arida et al. 1999).

\section{Brain Excision and Tissue Preparation for Nissl Staining}

Animals were euthanized 90 days after pilocarpine-induced SE (chronic phase). For this analysis, three animals per group were deeply anesthetized with a mixture of ketamine hydrochloride $(120 \mathrm{mg} / \mathrm{mL}$, i.p.) and xylazine $(9 \mathrm{mg} / \mathrm{mL}$, i.p.) and then rapidly perfused through the heart with four solutions in the following order: (i) $25 \mathrm{~mL}$ of Millonig's buffer; (ii) $50 \mathrm{~mL}$ of sodium sulfide fixative $0.1 \%$ in Millonig's buffer; (iii) $100 \mathrm{~mL}$ of glutaraldehyde 3\%; (iv) $200 \mathrm{~mL}$ of sodium sulfide fixative $0.1 \%$ in Millonig's buffer. Millonig's buffer was prepared 1 day before perfusion using $3.88 \mathrm{~g}$ of sodium hydroxide, $16.56 \mathrm{~g}$ of sodium phosphate monobasic, and $0.02 \mathrm{~g}$ of calcium chloride per liter of distilled water. The brains were cut on a cryostat $(32-\mu \mathrm{m}$-thick sections); all sections corresponding to an interval between -2.8 and $-5.8 \mathrm{~mm}$ from the bregma (Paxinos and Watson 2013) were collected, comprising a total sectioned extent of $3 \mathrm{~mm}$ per animal. Every third consecutive section was mounted onto a gelatin-coated slide and then processed for Nissl staining to assess the distribution and severity of neuronal damage, which was determined by cells $/ \mu^{2}$. The number of cells was counted only in the dorsal hippocampal subregions (dentate gyrus, CA1, CA3, and hilus), bilaterally, and in triplicate. This count was conducted by a researcher unaware of the treatment of the experimental groups with the help of an optical microscope (Nikon, Eclipse E600FN) with a checkered grid. The area of interest had two forbidden lines (exclusion) and two acceptable lines (inclusion). The cells 
that touched the forbidden lines were not counted, but those that touched the acceptable lines and were within the area of interest were counted. Each hippocampal subregion was divided into three fields, each field with $5000 \mu^{2}$. Thus, the outcome was determined by the average of field values.

\section{Statistical Analysis}

The Kruskal-Wallis test was used to assess differences between distinct groups. The Mann-Whitney test was used to evaluate differences between brain regions and gene expression changes within the same group. Gene silencing was confirmed in comparison with controls. For qPCR, analysis of variance (ANOVA) followed by Tukey's post hoc test was used to analyze messenger RNA (mRNA) levels; $p<0.05$ was considered a significant difference. For phenotype analysis, including mortality rate, we used one-way ANOVA followed by Tukey's post hoc test (seizure analysis). Differences in the number of cells counted in the hippocampal subregions (average field values) were accessed by one-way ANOVA followed by Tukey's post hoc test. Statistical analyses were carried out with the BioEstat v.5.0 program.

\section{Results}

\section{Two Tail Injections of II1 b siRNA::RVG-9R Successfully Decreased II1b Brain Expression with no Off-Target Effects}

We introduced a few modifications to the original procedure developed in mice (Kumar et al. 2007). First, we tested the possibility of reducing the number of injections from three to two (with an 8-h interval between injections). We observed that gene silencing using siRNA against $I l l b$ (sill1b) was dose-dependent, as the strongest knockdown effects $(>80 \%$ reduction in mRNA in the whole rat brain $48 \mathrm{~h}$ post-injection) was achieved using two tail injections of $50 \mu \mathrm{g}$ of siRNA (Supporting information, Fig. S1). However, because two injections of $25 \mu \mathrm{g}$ of siRNA yielded satisfactory gene silencing results ( $I l 1 b$ mRNA reduction close to $60 \%$ ), all subsequent experiments were performed with this smaller mass to avoid possible off-target effects, as recommended in the literature (Tschuch et al. 2008; Caffrey et al. 2011). Therefore, using only two intravenous tail injections, we observed that gene expression started to decline after $24 \mathrm{~h}$; the effect lasted for more than 3 days (Fig. 1).

Transvascular tail injections of sill1b resulted in significant gene silencing in different areas of the CNS (Supporting information, Fig. S2), which was observed $24 \mathrm{~h}$ postinjection (Fig. 1), with the maximum effect on mRNA levels

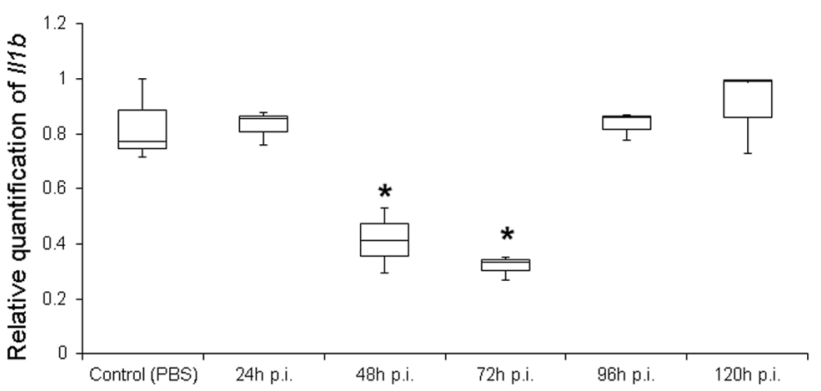

Fig. 1 Gene silencing effect of silllb over time. Animals were injected twice (8-h interval between injections) with $25 \mu \mathrm{g}$ of sill1b in the tail vein. Gene expression was quantified in the whole brain by real-time polymerase chain reaction (qPCR). Control animals were injected with phosphate-buffered saline (PBS) or siGFP (data not shown). All groups were composed of three animals. Asterisk indicates significant gene silencing (Kruskal-Wallis test, $p<0.05$ ). p.i., post-injection

occurring at $72 \mathrm{~h}$ after sill1 $\mathrm{b}$ injection, as determined by qPCR. Normal mRNA levels were restored by $96 \mathrm{~h}$ after sill1b injections (Fig. 1).

Two different strategies were used to assess RNAi specificity. Initially, we tested the effects of sill1b on the expression levels of Ptgs 2 and $N f k b$ (Supporting information, Fig. S1). As expected, two injections of $25 \mu \mathrm{g}$ led to an evident knockdown of both genes, an expected outcome because both genes are induced by Il1b (Soloff et al. 2006). Surprisingly, increasing the mass of sill1b to $50 \mu \mathrm{g}$ did not reduce Ptgs2. Indeed, we observed an increase in the expression of Ptgs2, making its expression similar to controls. This effect could be an indication of an off-target effect as Ptgs 2 could be induced by other biological pathways (Kaidi et al. 2006; Manieri et al. 2012). By contrast, siGFP (used as negative control) did not affect the expression of either of these genes (Supporting information, Fig. S1), clearly showing that RNAi was dependent on target sequence complementarity. The second approach to check for RNAi specificity focused on the expression of two genes not related to $I l l b$ : Ntrk2 and Plat. In this experiment, using sill1b and siGFP, there were no gene knockdown effects, as expected (Fig. 2).

\section{siRNA::RVG-9R Complexes did not Compromise BBB Integrity}

To verify whether the crossing of siRNA::RVG-9R complexes from the periphery to the CNS could induce significant damage to the BBB, we performed MRI in animals from two RNAi control groups (injected with PBS or siGFP) and in one RNAi experimental group (injected with sill1b) using Gd-DTPA as a paramagnetic contrast. As a positive control, we used animals that remained in pilocarpine-induced SE for $2 \mathrm{~h}$, which is known to damage the BBB (Marchi et al. 2007). After image acquisition, we 

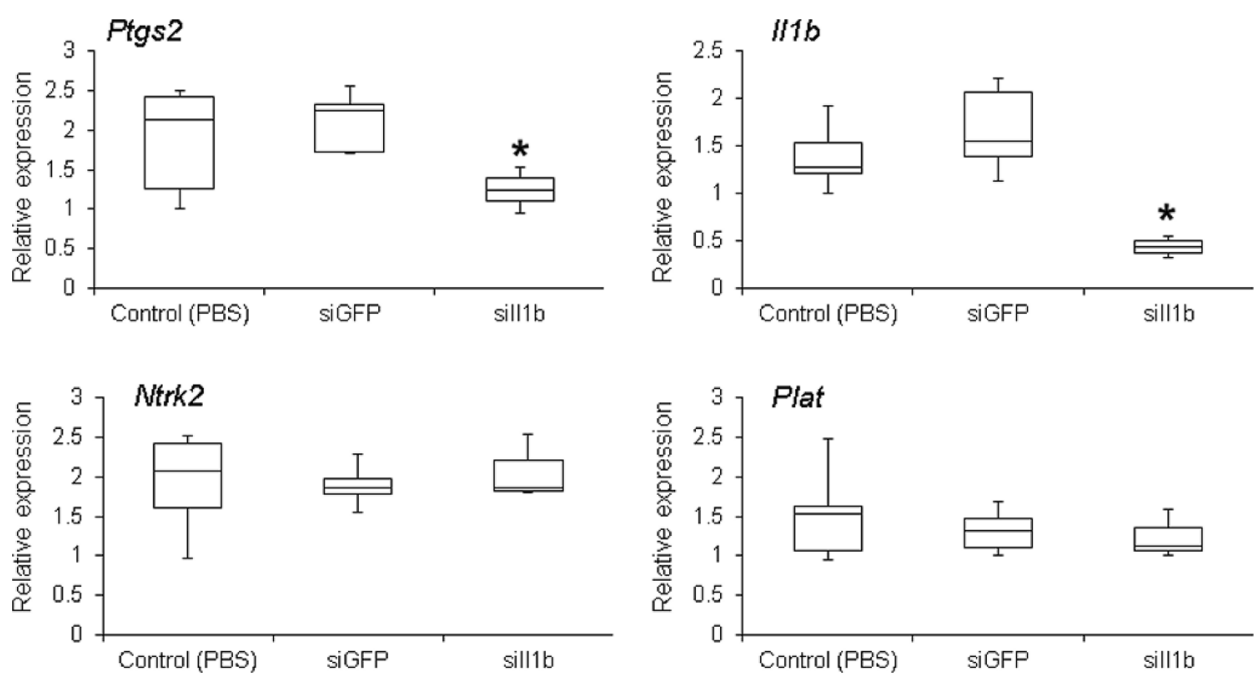

Fig. 2 Assessment of RNA interference specificity. Relative gene expression quantification [real-time polymerase chain reaction (qPCR)] of Ptgs2, Illb, Ntrk2, and Plat in animals that received two injections of $25 \mu \mathrm{g}$ of siRNA (8-h interval between injections). Brains were collected and RNA was extracted $72 \mathrm{~h}$ after the first injection. As expected, phosphate-buffered saline (PBS) alone or siGFP did not

affect the expression of any of the assessed genes. By contrast, sill1b led to the silencing of both $I l 1 \mathrm{~b}$ and Ptgs2 (which are in the same biological pathway as $I l l b$ ), whereas Ntrk2 and Plat (which are not biologically related to $I l l b$ ) were not affected. Each experiment was performed in the whole brain and extracted from five animals. Asterisk indicates significant gene silencing (Kruskal-Wallis test, $p<0.05$ )

selected two slices near the middle of the cerebrum and one in the hippocampal region for visual analysis (Fig. 3). There was no sign of BBB damage, although it is noteworthy that this approach considers the limitation of the paramagnetic contrast used (Gd-DTPA, molecular weight

nearly $550 \mathrm{~g} / \mathrm{mol}$ ), which can only assess BBB integrity for molecules of an equivalent size or larger. These data were enough to confirm that the complex of siRNA::RVG9R did not cause significant damage to the BBB.

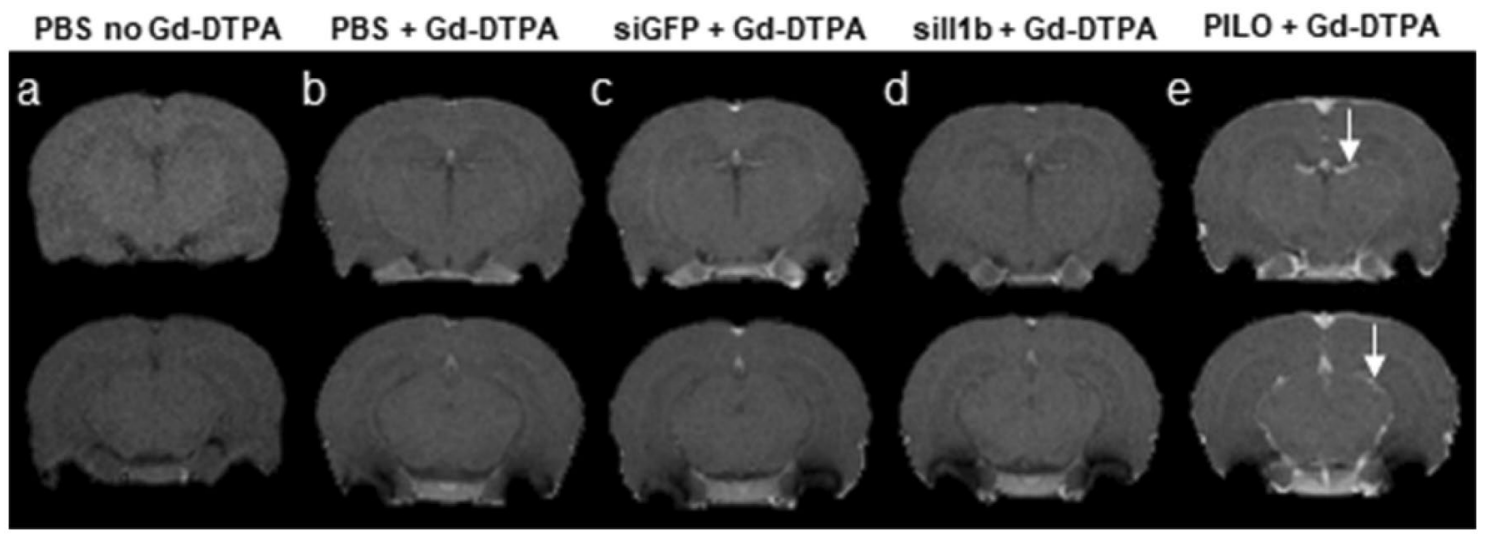

Fig. 3 Representative magnetic resonance images of animals used in our experiments with RNA interference. We selected two slices near the middle of the cerebrum and another one in the hippocampal region: a images from an animal that was injected with PBS but not paramagnetic contrast (gadolinium diethylenetriaminepentacetate [Gd-DTPA]); b animals injected with phosphate-buffered saline (PBS, control) followed by Gd-DTPA; c animals injected with siGFP::RVG9R followed by Gd-DTPA; $\mathbf{d}$ animals injected with siIllb::RVG9R followed by Gd-DTPA; and e animals injected with Gd-DTPA $2 \mathrm{~h}$ after status epilepticus induced by pilocarpine (PILO) injection (positive control). All groups were composed of three animals. The white arrows indicate the presence of Gd-DTPA (intensified signal) within the brain as a marker of BBB damage 


\section{Il1b mRNA Expression Showed a Rapid Increase $1 \mathrm{~h}$ After SE in the PILO Model}

To achieve timely knockdown of $I l l b$ in the brain, it was important to determine more precisely the time frame when the increase in expression takes place; therefore, we quantified $I l l b$ transcripts at short intervals (1, 3, 6 and $24 \mathrm{~h}$ ) after SE. Surprisingly, we observed a very early and rapid increase in $I l 1 b$ mRNA starting in the first hour after SE (Marchesini 2011). Continuing observations showed that within $6 \mathrm{~h}$ after SE, Illb mRNA expression showed a tenfold increase compared with control animals (Fig. 4). In addition, we observed a more modest upregulation of $I l 1 \mathrm{rn}$ (Fig. 4). Considering the very early increase in $I l l b$ expression in the course of pilocarpine-induced SE, we decided to inject sill1b $48 \mathrm{~h}$ before intraperitoneal pilocarpine administration. By doing so, we expected that, at the observed time of increased $I l l b$ expression, injection of sill $1 b$ would be able to control the striking pilocarpine-mediated $I l 1 b$ upregulation.
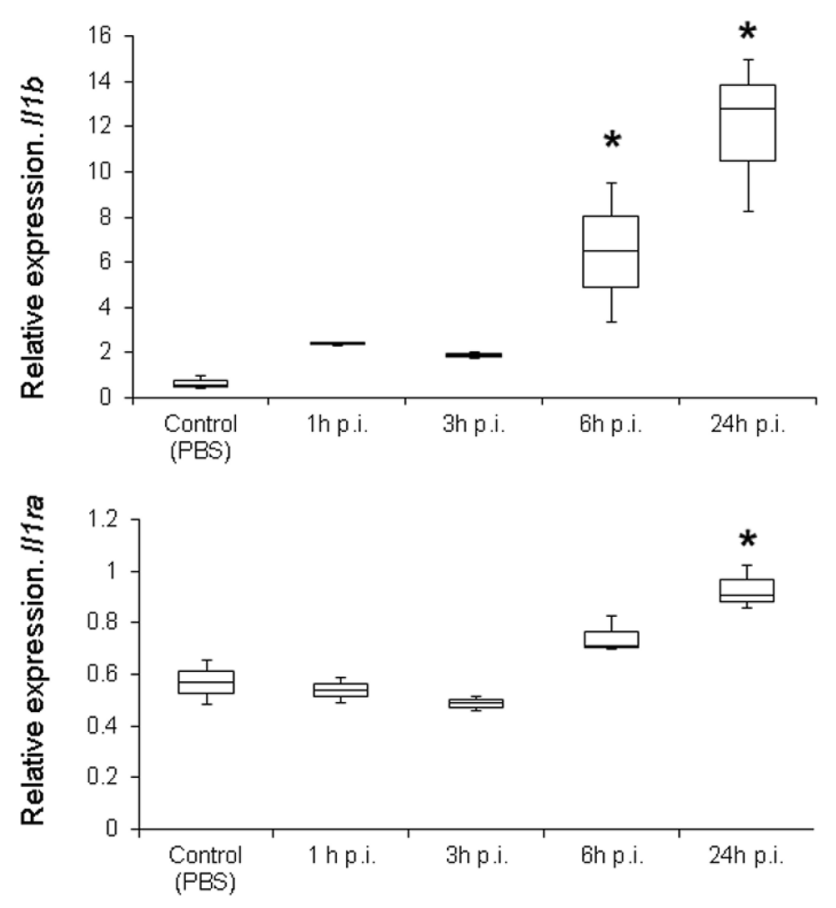

Hours after pilocarpine injection

Fig. $4 \mathrm{Ill} \mathrm{b}$ and Illrn gene expression profiles over time in the brain after pilocarpine injection. The expression profiles were generated by using real-time polymerase chain reaction (qPCR) of both genes $1,3,6$, and $24 \mathrm{~h}$ post-injection (p.i.) of pilocarpine and compared with control (no sill1b or pilocarpine administration). We observed an increase in $I l l b$ expression at $6 \mathrm{~h}$ p.i. All groups were composed of three animals. Asterisk indicates significant changes in gene expression (Kruskal-Wallis test, $p<0.05$ )
Il1b Knockdown Led to a More Severe Phenotype and Increased Animal Mortality in the Acute Phase of the PILO Model

For the animal mortality analysis, we injected 50 animals with pilocarpine; 42 (84\%) developed SE. However, three animals were excluded from further experiments due to technique failure during siRNA injection in the tail vein. Thus, we had a total of 39 animals for the animal mortality analysis.

There were no significant differences in the death rates among the groups in the period immediately following SE (first day): controls $(8 / 19)=19 \%$; animals injected with sill1b $(4 / 9)=22 \%$; and animals injected with sill1rn $(2 / 11)=25 \%$. Nonetheless, 5 days after SE, we observed significant differences in animal mortality, as follows: controls $(9 / 19)=47 \%$; animals injected with sill1b $(6 / 9)=66 \%$; and animals injected with sill1rn $(3 / 11)=27 \%\left(\chi^{2}, p<0.05\right.$ compared with the control group) (Supporting information, Table S1).

The time intervals between pilocarpine injection and the first observed seizure were: 34 min [standard deviation $(\mathrm{SD})=12]$ in controls, $26 \mathrm{~min}(\mathrm{SD}=14)$ in animals preinjected with sill1b (ANOVA and Tukey's test, $p<0.05$ ), and $49 \mathrm{~min}(\mathrm{SD}=16)$ in animals pre-injected with sill1 $\mathrm{rn}$ (Fig. 5A). There were no significant differences among the groups (ANOVA and Tukey's test, $p>0.05$ ).

In addition, there were significant differences in the onset of SE between the control group and both treated groups. The time intervals between pilocarpine injection and SE were: $58 \min (\mathrm{SD}=19)$ in controls, $46 \min (\mathrm{SD}=25)$ in animals pre-injected with sill1b (ANOVA and Tukey's test, $\mathrm{p}<0.01)$, and $70 \mathrm{~min}(\mathrm{SD}=18)$ in animals pre-injected with sill1rn (ANOVA and Tukey's test, $p<0.01$ ) (Fig. 5B).

\section{SIc1a3, a Glutamate Re-Uptake Transporter, was Downregulated $48 \mathrm{~h}$ After Il1b siRNA Injection}

We analyzed the expression of several genes related to the Illb signaling pathway as well as glutamate re-uptake in the synaptic cleft. We aimed to gain additional information regarding Il1b signaling pathway regulation, as well as to investigate the possible involvement of glutamatemediated damage induced by changes in $I l l b$ expression. Experiments were carried out $48 \mathrm{~h}$ after siRNA was injected so that the molecular effects of gene silencing were at the maximum. For genes related to the Il1b pathway, we observed an increase in Tnf expression after sill1rn treatment. Furthermore, we observed a decrease in the mRNA expression of Slcla3 (also known as Eaat1), which is one of the most important glutamate re-uptake transporters in the CNS, when $I l l b$ had been silenced 
Fig. 5 Phenotype assessment during the acute phase of the pilocarpine-induced epilepsy model. a The onset for the first seizure was 34 min (standard deviation $[\mathrm{SD}]=12$ ) in controls, $26 \min (\mathrm{SD}=14)$ in animals pre-injected with sill $1 b$, and 49 min $(\mathrm{SD}=16)$ in animals pre-injected with sill1rn. b The onset of the status epilepticus (SE) was: $58 \mathrm{~min}(\mathrm{SD}=19)$ in controls, $46 \min (\mathrm{SD}=25)$ in animals pre-injected with sill1b, and $70 \mathrm{~min}(\mathrm{SD}=18)$ in animals pre-injected with sill1rn. Single and double asterisk indicate a significant difference compared with the control group (analysis of variance with Tukey's test, $p<0.05$ and $p<0.01$, respectively) a

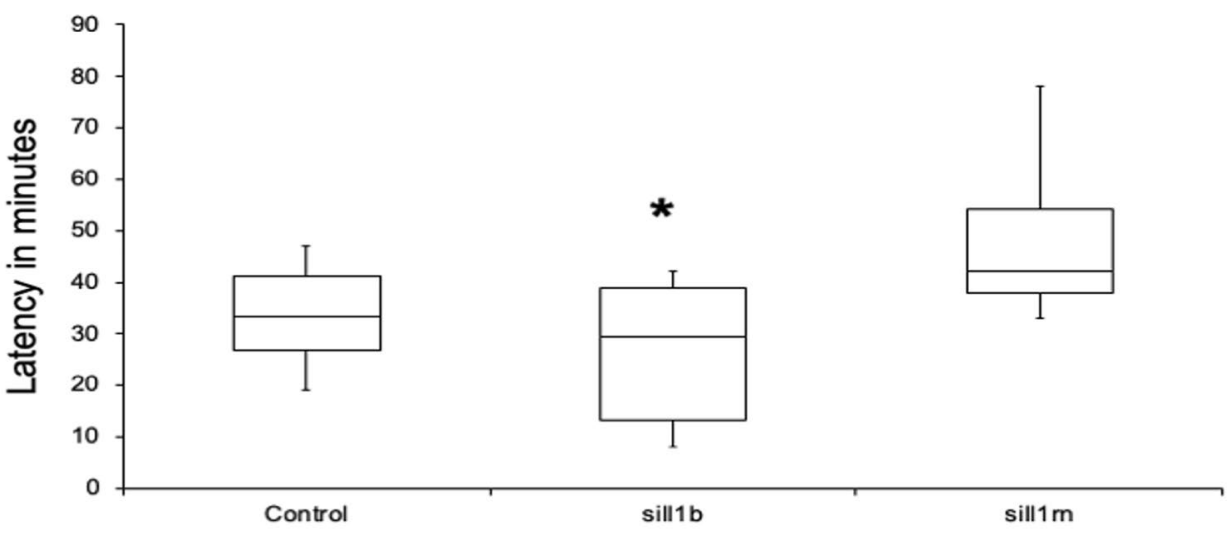

b

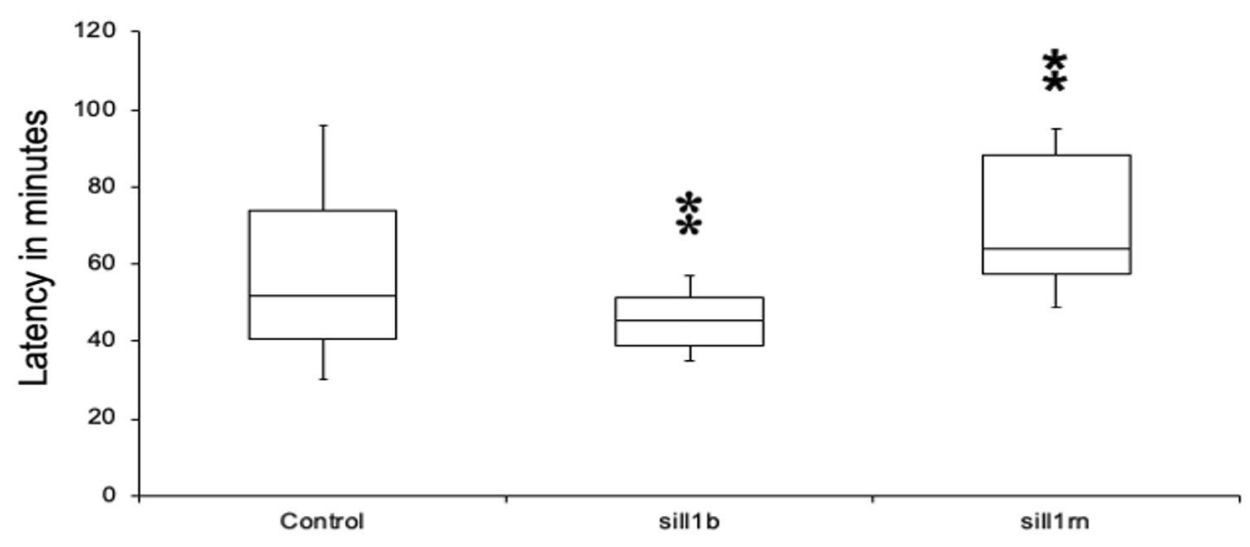

First Seizure

Status Epilepticus
(Fig. 6). The opposite effect (increased Slcla3 mRNA expression) was observed when Ill $r n$ had been silenced.

\section{II1rn Knockdown Induced an Increase in the Expression of Genes Known to be Overexpressed in the Silent Phase of the PILO Model}

We investigated whether changes in the expression of several genes related to the silent phase of the PILO model could be induced by the transient knockdown of Illrn in the acute phase. We found that genes expressed in the silent phase, such as Npy, Plat, and Ntrk2 (Becker et al. 2003; He et al. 2004; Koyama and Ikegaya 2005), were upregulated in animals in which Ill rn had been silenced (Supporting information, Fig. S3). In addition, we still observed the upregulation of $N f k b$ induced by sill1rn, which had been documented in the acute phase. Unfortunately, we could not perform a similar experiment in animals in which $I l l b$ had been silenced due to the high mortality rate observed in that group.

\section{Transient Knockdown of Il1rn Decreased Neuronal Loss in the Hippocampus}

To determine whether the molecular changes induced by the transient knockdown of Il1rn in the acute phase could lead to significant repercussions in the chronic phase of the PILO model, we analyzed hippocampal tissue 3 months after SE using histological staining (Fig. 7). Nissl staining revealed significant less neuronal loss in all the hippocampi fields of the animals in which Illrn had been silenced (ANOVA and Tukey's test, $p<0.01$ ). The mean number of remaining, live cells in control versus Illrn silenced groups are as follows, DG: $19.1 \pm 0.6$ versus $23.2 \pm 0.3$ cells $/ \mu^{2}$; hilus: $7.4 \pm 0.2$ versus $8.4 \pm 0.2$ cells $/ \mu \mathrm{m}^{2}$; CA1: $14.2 \pm 0.4$ versus $15.6 \pm 0.4$ cells/ $\mu \mathrm{m}^{2}$ and CA3: $5.8 \pm 0.2$ versus $7.4 \pm 0.3$ cells $/ \mu \mathrm{m}^{2}$. 
Fig. 6 Analysis of gene expression $48 \mathrm{~h}$ after sill1b or sill1rn injection (no pilocarpine administration). Real-time polymerase chain reaction (qPCR) was used to determine the messenger RNA (mRNA) levels of $I l l b, I l l r n, N f k b$, and Slcla3 in animals injected with silllb or sill1rn. Control animals were injected with phosphate-buffered saline (PBS). All groups were composed of five animals. Single and double asterisk indicate a significant difference in gene expression (Kruskal-Wallis test, $p<0.05$ and $p<0.01$, respectively)
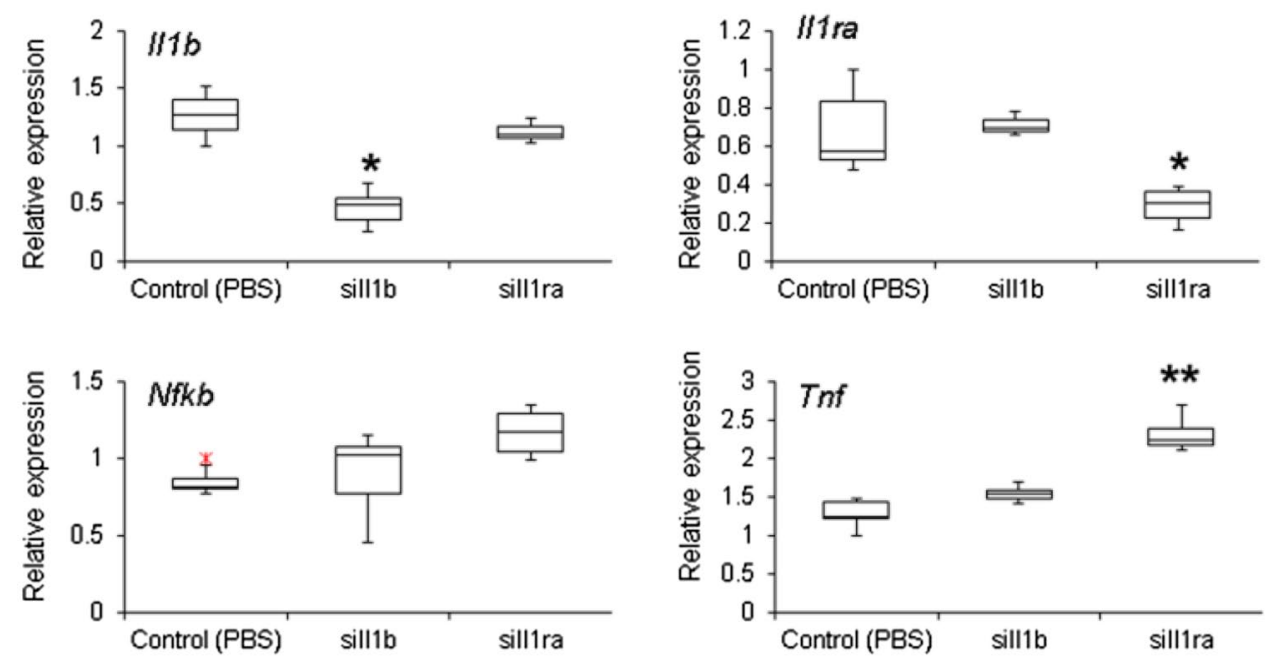
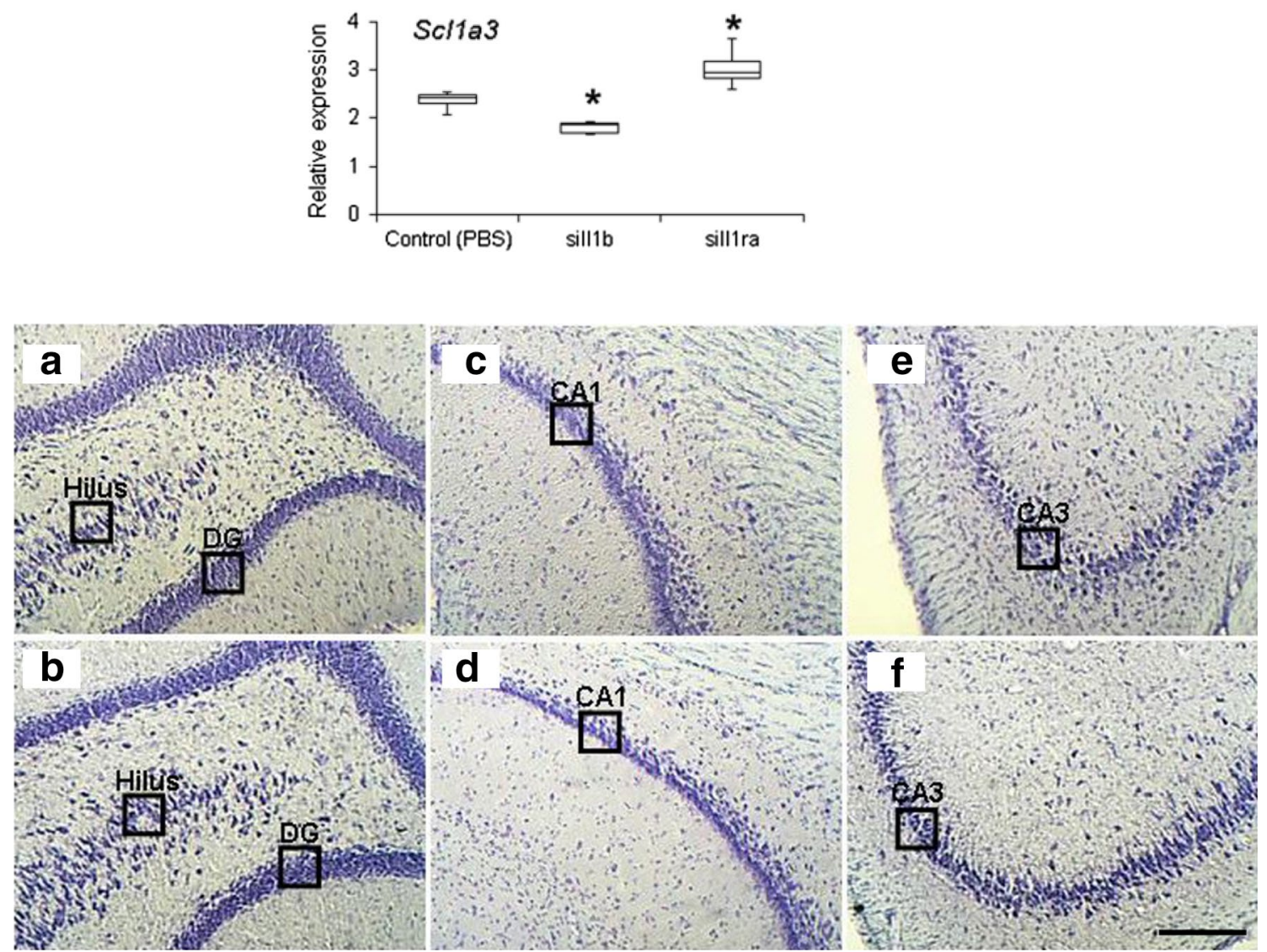

Fig. 7 Nissl staining of the hippocampal subfields for neuronal count $\left(\right.$ cells $/ \mu^{2}$ ) of animals in the chronic phase of the pilocarpine model. Animals injected twice (8-h interval between injections) with $25 \mu \mathrm{g}$ of sill1 $\mathrm{rn}$ in the tail vein $48 \mathrm{~h}$ before pilocarpine administration and survived after status epilepticus were kept under observation for 90 days. The images show the following: a hilus and DG, $\mathbf{c}$ CA1, and e CA3 regions of control animals injected with pilocarpine and PBS; b hilus and DG, $\mathbf{d} \mathrm{CA} 1$, and $\mathbf{f} \mathrm{CA} 3$ regions of animals pre-treated with of sill1rn. We observed a discrete neuronal loss in the hilus, DG, CA1, and CA3 regions in animals pre-treated with sill1rn (ANOVA and Tukey's test, $p<0.01)$. Scale bar $180 \mu \mathrm{m}$ 


\section{Discussion}

In the present study, we explored the role of $I l 1 b$ and its endogenous antagonist $(\mathrm{Ill} \mathrm{rn})$ in a rat model of MTLE induced by pilocarpine injection. For this endeavor, we used targeted delivery of siRNA by conjugating them to the RVG-9R peptide (Allan et al. 2005; Kim et al. 2010). We succeed in specifically downregulating $I l l \mathrm{~b}$ and $I l l \mathrm{rn}$ for $72 \mathrm{~h}$ (Figs. 1, 2) without damaging the BBB (Fig. 3). We injected siRNA against $I l l b$ and Ill $r n 48 \mathrm{~h}$ before pilocarpine treatment due to the rapid increase in $I l 1 b$, but not Ill rn, observed $1 \mathrm{~h}$ after pilocarpine injection (Fig. 4). We found that knocking down endogenous $I l l b$ in the CNS led to a decrease in the onset of the first seizure as well as SE (Fig. 5). By contrast, animals in which Illrn has been silenced, and therefore presented increased Illb signaling, showed the opposite effect (Fig. 5). Moreover, animals in which $I l 1 b$ had been silenced showed an increase in mortality after 5 days of SE; the opposite effect was observed in animals in which Illrn had been silenced (Supplementary information, Table S1). Even though we did not quantify $I l l b$ and $I l l r n$ mRNA transcripts or other inflammatory mediators such as interleukin-converting enzyme (ICE/caspase-1) during the acute phase of the PILO model, the data of the siRNA specificity (Fig. 6) and dynamics of $I l 1 \mathrm{~b}$ and $I l 1 \mathrm{rn}$ expression after pilocarpine administration (Fig. 4) indicates that the effect observed during the acute phase of the PILO model in the sill1b group is likely influenced by the specific knockdown of the $I l l b$ gene and not by changes in expression of $I l l \mathrm{rn}$, because the latter is not affected by $I l l b$ silencing (Fig. 6). We also hypothesize that even with the activation of inflammatory cascades and specially ICE/caspase-1 during the acute phase of the PILO model, the lower expression of $I l l b$ RNA in the sill1b group ultimately produces less mature I11b (Fig. 5). In addition, we observed that it takes at least $18 \mathrm{~h}$ after pilocarpine injection for Ill $\mathrm{rn}$ expression to increase in the brain (Fig. 4). This delay is surprising, and it contrasts with what has been observed in the periphery, where Ill rn shows an increased expression $4 \mathrm{~h}$ after an inflammatory insult (Zahedi et al. 1991), suggesting that the brain is much less effective than the periphery in inducing a crucial mechanism for rapidly terminating the effects of a sustained increase in endogenous Illb.

Thus, the major finding of this study, as shown by the mortality observed after SE, and by the decrease in the expression of the glutamate reuptake transporter Slcla3 $48 \mathrm{~h}$ after $I l l b$ knockdown, is that endogenous $I 11 \mathrm{~b}$ seems to influence animal survival after SE during the acute phase of the PILO model. Our interpretation for this observation is that by silencing $I l 1 b$, there is a decrease in the expression of SCLIa3; on the contrary, silencing the
$I l l b$ antagonist, using siRNA against $I l 1 r n$, increases the expression of Sclla3. In this way, when $\mathrm{Il1} \mathrm{b}$ is reduced there is a slower withdrawal of glutamate from the synaptic cleft, increasing its excitotoxic effect. Thus, decreasing the basal production of Il1b before SE somehow affects the CNS milieu and makes the tissue more vulnerable to hyperexcitability.

One hypothesis to explain the effect of Illb in neuronal excitability is that it directly inhibits $\mathrm{K}^{+}$efflux and increases $\mathrm{Ca}^{2+}$ influx and NMDA-R function, all of which contribute to seizure susceptibility and seizure-related damage (Meini et al. 2000; Viviani et al. 2003; Zhu et al. 2006; Eyo et al. 2014, 2018; Tian et al. 2017). More recently, several studies have begun to unravel the non-immunological roles played by endogenously produced Illb in the brain; this molecule is crucial to maintain homeostasis and is far from neurotoxic (for an extensive review, see Hewett et al. 2012; Liu and Quan 2018). Furthermore, studies involving ILIB polymorphisms in humans have shown an association between a variant located at the promoter region of $I L 1 B$ (C-511T), which produces less protein, and increased risk for epilepsy and febrile seizure (Wen et al. 2006; Al Morshedy et al. 2017). These findings support the hypothesis that endogenous Illb may also have protective roles in the CNS and that insufficient endogenous Illb predisposes the CNS to hyperexcitability. In addition, under physiological conditions, Il1b seems to modulate several functions in the CNS, such as regulating sleep (De Sarro et al. 1997; Krueger et al. 1998) and promoting learning and long-term potentiation (LTP) (Bellinger et al. 1993; Schneider et al. 1998; Ikegaya et al. 2003; del Rey et al. 2013). Chronic overexpression of $I l l b$ in brain areas such as the hippocampus have been implicated in impaired spatial memory (Moore et al. 2009) and in contextual fear memory (Matousek et al. 2010) in conditional transgenic mice, and with seizure susceptibility in animal models of sleep fragmentation (Grubac et al. 2021) and prostatitis (Sutulovic et al. 2019). By contrast, transgenic mice with deficient Il1b signaling or pharmacological inhibition of CNS Illb also present with memory and learning impairment (Avital et al. 2003; Goshen et al. 2007). More recently, it has been observed that NMDA-R together with Illb appear to be necessary to induce the CX3CR1-dependent microglial process convergence (MPC) - an increase in the interaction between microglia and neurons, especially in the dendrites and axons, that confers neuroprotective effects in chemically induced animal models of epilepsy, thereby decreasing seizure severity and cell death (Eyo et al. 2016, 2018). Interestingly, the results described above seem to be in contradiction with the previously observed effect of Il1b-driven NMDA-R activation contributing to seizure severity (Meini et al. 2000; Viviani et al. 2003; Zhu et al. 2006; Eyo et al. 2014, 2018; Tian et al. 2017). However, these complex regulatory functions of Illb are most likely time and dosage-dependent (Liu 
and Quan 2018), and any disruption in the balance of endogenous production may potentially lead to impaired functions.

Another important issue that is relevant for the interpretation of previous results in the literature and our current study is that there are relevant limitations to many previous studies regarding the strategies used to assess animal $\mathrm{Ill}$ b expression and activity or to deliver this molecule and its antagonists into the CNS. In most studies, researchers have used stereotactic surgery for this purpose (Panegyres and Hughes 1998; Vezzani et al. 1999, 2000, 2002; Yuhas et al. 1999; De Simoni et al. 2000; Yi et al. 2004; Dube et al. 2005; Heida and Pittman 2005; Sayyah et al. 2005). This procedure can potentially induce further inflammatory changes, which may make it challenging to study the genes involved in inflammatory pathways. Indeed, in the present study, we observed the activation of genes related to inflammation in the CNS after sham stereotactic surgery (Supporting information, Fig. S4). As pointed out by Hewett et al. (2012), the route of administration of the convulsant (local or systemic) when combined with exogenously applied Illb can lead to contradictory roles for Illb in the context of epileptogenesis.

Although researchers have reported remarkable results using siRNA in various organs, the CNS remains a difficult target mainly due to the protection of the BBB and to the degree of cellular diversity (Hassani et al. 2005; Pardridge 2007). Many protocols for the in vivo delivery of siRNA into the CNS use intrathecal injection associated with a cofactor, and stereotaxic surgery is needed in all cases (for a review, see Schlachetzki et al. 2004). In addition to their invasiveness, these approaches promote only restricted silencing, limited to the injection site. Furthermore, adenovirus and retrovirus transduction protocols promote gene silencing in a variety of cell types in the CNS; however, this is also a limited strategy because an injection into the cerebral parenchyma is needed.

Furthermore, inflammatory responses (triggered by the viral vector) may interfere with molecular and phenotypic analyses (Jooss and Chirmule 2003; Lowenstein and Castro 2003). Thus, the strategy of using siRNA conjugated to a short peptide derived from the RVG has emerged as a simple and less invasive strategy for promoting gene knockdown in different areas of the CNS; this method allows for the intravenous delivery of siRNA into the brain (Kumar et al. 2007). In our experiment, we observed effective gene knockdown in several areas restricted to the CNS (Supporting information, Fig. S2), and this information may be useful for planning future experiments. Even though this non-invasive in vivo delivery technique was effective for knocking down genes in the CNS, a lingering concern was the possibility of significant damage to the BBB by the use of siRNA::RVG-9R complexes. We were able to rule out this possibility using MRI, showing that treatment with different siRNA::RVG9R complexes did not alter BBB permeability to molecules equal in size or larger than Gd-DTPA, the paramagnetic contrast used in our experiments (molecular weight of approximately $550 \mathrm{~g} / \mathrm{mol}$ ).

siRNA emerged in the early 2000 s as a promising biological and therapeutic tool, but there are considerable limitations that need to be addressed when applying this method to functional studies (Jackson and Linsley 2010). Among these, off-target effects are of special concern (Jackson and Linsley 2004; Jackson et al. 2006). We assessed this issue carefully and only observed evidence of off-target effects when using high concentrations of siRNA (two 50- $\mu$ g injections); in this scenario, we found that expression of Ptgs 2 was affected as described previously as evidence of the oversaturation of RNAi machinery (Tschuch et al. 2008). The gene silencing effects observed in this study were temporary and present only during the acute phase; nonetheless, we were able to detect molecular and phenotypic changes that persisted beyond this period in the group in which Illrn has been knocked down. Indeed, we observed that animals in which Ill $r n$ had been knocked down $48 \mathrm{~h}$ before pilocarpine injection displayed an even greater upregulation of genes known to be overexpressed in the silent phase of the PILO model (Plat, Ntrk2, and Npy; Fig. 6).

Surprisingly, the changes in gene expression induced by temporarily knocking down Illrn $48 \mathrm{~h}$ before pilocarpine injection were able to induce a decrease in neuronal death, detected by Nissl staining, in the chronic phase of the PILO model, as indicated by the cell counting data. Previous experiments using the pre-treatment of hippocampal cell cultures with agents that activate nuclear factor kappa-lightchain-enhancer of activated B cells (NF- $\mathrm{KB}$ ) have shown that this approach can prevent neuronal apoptosis in vitro, or that inhibition of NF- $\mathrm{kB}$ function results in apoptosis of rat PC12 cells (Mattson et al. 1997; Taglialatela et al. 1997). Thus, we hypothesize that modifying gene expression in the acute phase of the PILO model may have lasting effects.

\section{Conclusion}

Even though our study has limitations, such as the absence of $I l l b$ and Ill $r n$ transcript quantification during the acute phase of the PILO model, we have provided suggestive evidence that endogenously produced $I l l b$ seems to have a role in homeostatic maintenance in the CNS under physiological conditions. In addition, this effect appears to be relevant for animal recovery after the initial insult due to SE. Although pending further investigation, we believe that our results are sufficient to challenge the previous hypothesis that nonspecific inhibition of inflammation is universally beneficial and urge caution regarding the proposal of using broad-spectrum anti-inflammatory agents to prevent epilepsy after an insult (Vezzani et al. 2011). Furthermore, we have shown for the first time the feasibility 
of studying and manipulating neuroinflammation in the CNS in a noninvasive and specific way within the context of epilepsy. With the recent Food and Drug Administration (FDA) approval of drug therapy for hereditary transthyretin-mediated amyloidosis based on siRNA (FDA 2018), our findings open new perspectives for applying RNAi to diseases of the CNS and encourage the development of new noninvasive delivery methods targeting specific cell types.

Supplementary Information The online version contains supplementary material available at https://doi.org/10.1007/s10571-022-01190-y.

Acknowledgements This work was supported by Grants from Fundação de Amparo à Pesquisa do Estado de São Paulo (FAPESP, Grant \# 2013/07559-3 and 2005/56663-1), São Paulo, Brazil, and Coordenação de Aperfeiçoamento de Pessoal de Nível Superior (CAPES), Brazil, Grant number \# 001.V.D.B.P., R.B.M., J.M.M., and R.S.P. were the recipients of scholarships from FAPESP, São Paulo, Brazil. L.C., E.A.C., F.C., and I.L.-C. are supported by Conselho Nacional de Desenvolvimento Científico e Tecnológico (CNPq), Grant \# 403299/2016-0 and 309494/2014-1. Preliminary data related to this manuscript has been published as an extended abstract: Pascoal VDB, Marchesini R, Matos AHB et al. (2010) A Interleucina 1 beta mostra uma ação protetora na fase aguda do modelo de epilepsia induzido pela pilocarpine. J Epilepsy Clin Neurophysiol 16:97-99. In addition, the work reported here is part of the Ph.D. thesis of V.D.B.P., and of R.B.M. presented at the School of Medical Sciences, University of Campinas (UNICAMP), Campinas, Brazil, June, 23, 2010, and November, 1, 2011. Both academic publications are deposited online in the UNICAMP institution electronic repository and can be found at: http:// repositorio.unicamp.br/jspui/handle/REPOSIP/309738 and http://repos itorio.unicamp.br/jspui/handle/REPOSIP/309730.

Author Contributions IL-C, FC, and ASV conceived the study, designed the experiments, and drafted the manuscript. VDBP, RBM, MCPA, AHBM, FFC, RG, and LBP performed the animal experiments, tissue collection, and qPCR. TCP designed the siRNA and helped with the interpretation of the results. RS performed statistical analysis. JMM, RSP, and AT performed the imaging experiment. EAC, LC, and AT offered advice on data analysis and manuscript preparation. IL-C supervised the project. All authors discussed and commented on the manuscript.

Data Availability Not applicable.

Code Availability Not applicable.

\section{Declarations}

Conflict of interest None of the authors have any conflict of interest to disclose.

Ethical Approval The experimental protocols were approved by the Ethics Committee in Animal Experimentation at the University of Campinas (UNICAMP).

Open Access This article is licensed under a Creative Commons Attribution 4.0 International License, which permits use, sharing, adaptation, distribution and reproduction in any medium or format, as long as you give appropriate credit to the original author(s) and the source, provide a link to the Creative Commons licence, and indicate if changes were made. The images or other third party material in this article are included in the article's Creative Commons licence, unless indicated otherwise in a credit line to the material. If material is not included in the article's Creative Commons licence and your intended use is not permitted by statutory regulation or exceeds the permitted use, you will need to obtain permission directly from the copyright holder. To view a copy of this licence, visit http://creativecommons.org/licenses/by/4.0/.

\section{References}

Al Morshedy S, Elsaadany HF, Ibrahim HE et al (2017) Interleukin-1 $\beta$ and interleukin-1receptor antagonist polymorphisms in Egyptian children with febrile seizures: a case-control study. Medicine 96:e6370. https://doi.org/10.1097/MD.0000000000006370

Allan SM, Tyrrell PJ, Rothwell NJ (2005) Interleukin-1 and neuronal injury. Nat Rev Immunol 5:629-640. https://doi.org/10.1038/ nri1664

Arida RM, Scorza FA, Peres CA, Cavalheiro EA (1999) The course of untreated seizures in the pilocarpine model of epilepsy. Epilepsy Res 34:99-107. https://doi.org/10.1016/s0920-1211(98)00092-8

Arzimanoglou A, Hirsch E, Nehlig A et al (2002) Epilepsy and neuroprotection: an illustrated review. Epileptic Disord 4:173-182

Avital A, Goshen I, Kamsler A et al (2003) Impaired interleukin-1 signaling is associated with deficits in hippocampal memory processes and neural plasticity. Hippocampus 13:826-834. https://doi.org/ 10.1002/hipo.10135

Becker AJ, Chen J, Zien A et al (2003) Correlated stage- and subfieldassociated hippocampal gene expression patterns in experimental and human temporal lobe epilepsy. Eur J Neurosci 18:2792-2802. https://doi.org/10.1111/j.1460-9568.2003.02993.x

Bellinger FP, Madamba S, Siggins GR (1993) Interleukin 1 beta inhibits synaptic strength and long-term potentiation in the rat CA1 hippocampus. Brain Res 628:227-234. https://doi.org/10.1016/ 0006-8993(93)90959-q

Bender RA, Dubé C, Baram TZ (2004) Febrile seizures and mechanisms of epileptogenesis: insights from an animal model. Adv Exp Med Biol 548:213-225. https://doi.org/10.1007/978-1-47576376-8_15

Benson MJ, Manzanero S, Borges K (2015) Complex alterations in microglial M1/M2 markers during the development of epilepsy in two mouse models. Epilepsia 56:895-905. https://doi.org/10. 1111/epi.12960

Bernardino L, Ferreira R, Cristóvao AJ et al (2005) Inflammation and neurogenesis in temporal lobe epilepsy. Curr Drug Targets CNS Neurol Disord 4:349-360. https://doi.org/10.2174/1568007054 546171

Borges MA, Min LL, Guerreiro CAM et al (2004) Urban prevalence of epilepsy: populational study in São José do Rio Preto, a mediumsized city in Brazil. Arq Neuropsiquiatr 62:199-204. https://doi. org/10.1590/s0004-282x2004000200002

Caffrey DR, Zhao J, Song Z et al (2011) siRNA off-target effects can be reduced at concentrations that match their individual potency. PLoS ONE 6:e21503. https://doi.org/10.1371/journal.pone.00215 03

Cardim DA, Frigieri GH, Cabella BCT et al (2016) Characterization of intracranial pressure behavior in chronic epileptic animals: a preliminary study. Acta Neurochir Suppl 122:329-333. https:// doi.org/10.1007/978-3-319-22533-3_65

Carter DS, Deshpande LS, Rafiq A et al (2011) Characterization of spontaneous recurrent epileptiform discharges in hippocampalentorhinal cortical slices prepared from chronic epileptic animals. Seizure 20:218-224. https://doi.org/10.1016/j.seizure.2010.11. 022 
Cavalheiro EA, Leite JP, Bortolotto ZA et al (1991) Long-term effects of pilocarpine in rats: structural damage of the brain triggers kindling and spontaneous recurrent seizures. Epilepsia 32:778-782. https://doi.org/10.1111/j.1528-1157.1991.tb05533.x

Curia G, Longo D, Biagini G et al (2008) The pilocarpine model of temporal lobe epilepsy. J Neurosci Methods 172:143-157. https:// doi.org/10.1016/j.jneumeth.2008.04.019

De Sarro G, Gareri P, Sinopoli VA et al (1997) Comparative, behavioural and electrocortical effects of tumor necrosis factor-alpha and interleukin-1 microinjected into the locus coeruleus of rat. Life Sci 60:555-564. https://doi.org/10.1016/s0024-3205(96) 00692-3

De Simoni MG, Perego C, Ravizza T et al (2000) Inflammatory cytokines and related genes are induced in the rat hippocampus by limbic status epilepticus. Eur J Neurosci 12:2623-2633. https://doi.org/10.1046/j.1460-9568.2000.00140.x

del Rey A, Balschun D, Wetzel W et al (2013) A cytokine network involving brain-borne IL-1 $\beta$, IL-1ra, IL-18, IL-6, and TNF $\alpha$ operates during long-term potentiation and learning. Brain Behav Immun 33:15-23. https://doi.org/10.1016/j.bbi.2013.05.011

Dubé C, Vezzani A, Behrens M et al (2005) Interleukin-1beta contributes to the generation of experimental febrile seizures. Ann Neurol 57:152-155. https://doi.org/10.1002/ana.20358

Dudek FE, Sutula TP (2007) Epileptogenesis in the dentate gyrus: a critical perspective. Prog Brain Res 163:755-773. https://doi. org/10.1016/S0079-6123(07)63041-6

Eyo UB, Peng J, Swiatkowski P et al (2014) Neuronal hyperactivity recruits microglial processes via neuronal NMDA receptors and microglial P2Y12 receptors after status epilepticus. J Neurosci 34:10528-10540. https://doi.org/10.1523/JNEUROSCI.041614.2014

Eyo UB, Peng J, Murugan M et al (2016) Regulation of physical microglia-neuron interactions by fractalkine signaling after status epilepticus. eNeuro. https://doi.org/10.1523/ENEURO. 0209-16.2016

Eyo UB, Bispo A, Liu J et al (2018) The GluN2A subunit regulates neuronal NMDA receptor-induced microglia-neuron physical interactions. Sci Rep 8:828. https://doi.org/10.1038/s41598-018-19205-4

Fabene PF, Marzola P, Sbarbati A, Bentivoglio M (2003) Magnetic resonance imaging of changes elicited by status epilepticus in the rat brain: diffusion-weighted and $\mathrm{T} 2$-weighted images, regional blood volume maps, and direct correlation with tissue and cell damage. Neuroimage 18:375-389. https://doi.org/10.1016/s10538119(02)00025-3

FDA (2018) FDA approves first-of-its kind targeted RNA-based therapy to treat a rare disease. https://www.fda.gov/NewsEvents/ Newsroom/PressAnnouncements/UCM616518.htm?utm_campa ign=08102018_PR_FDA\%20approves\%20new\%20drug\%20for\% 20rare\%20disease $\% 2 \mathrm{C} \% 20 \mathrm{hATTR} \&$ utm_medium=email\&utm source=Eloqua. Accessed 17 Sept 2018

Garzillo CL, Mello LEAM (2002) Characterization of reactive astrocytes in the chronic phase of the pilocarpine model of epilepsy. Epilepsia 43(Suppl 5):107-109. https://doi.org/10.1046/j.15281157.43.s.5.40.x

González MI, Grabenstatter HL, Cea-Del Rio CA et al (2015) Seizurerelated regulation of GABAA receptors in spontaneously epileptic rats. Neurobiol Dis 77:246-256. https://doi.org/10.1016/j.nbd. 2015.03.001

Goshen I, Kreisel T, Ounallah-Saad H et al (2007) A dual role for interleukin-1 in hippocampal-dependent memory processes. Psychoneuroendocrinology 32:1106-1115. https://doi.org/10.1016/j. psyneuen.2007.09.004

Grubač Ž, Šutulović N, Jerotić D et al (2021) Experimental chronic sleep fragmentation alters seizure susceptibility and brain levels of interleukins $1 \beta$ and 6. Acta Neurobiol Exp 81:96-109. https:// doi.org/10.21307/ane-2021-010
Hamani C, Tenório F, Mendez-Otero R, Mello LE (1999) Loss of NADPH diaphorase-positive neurons in the hippocampal formation of chronic pilocarpine-epileptic rats. Hippocampus 9:303313. https://doi.org/10.1002/(SICI)1098-1063(1999)9:3\%3c303:: AID-HIPO9\%3e3.0.CO;2-Z

Hassani Z, Lemkine GF, Erbacher P et al (2005) Lipid-mediated siRNA delivery down-regulates exogenous gene expression in the mouse brain at picomolar levels. J Gene Med 7:198-207. https://doi.org/ 10.1002/jgm.659

He X-P, Kotloski R, Nef S et al (2004) Conditional deletion of TrkB but not BDNF prevents epileptogenesis in the kindling model. Neuron 43:31-42. https://doi.org/10.1016/j.neuron.2004.06.019

Heida JG, Pittman QJ (2005) Causal links between brain cytokines and experimental febrile convulsions in the rat. Epilepsia 46:1906-1913. https://doi.org/10.1111/j.1528-1167.2005. 00294.x

Hewett SJ, Jackman NA, Claycomb RJ (2012) Interleukin-1 $\beta$ in central nervous system injury and repair. Eur J Neurodegener Dis $1: 195-211$

Ikegaya Y, Delcroix I, Iwakura Y et al (2003) Interleukin-1beta abrogates long-term depression of hippocampal CA1 synaptic transmission. Synapse 47:54-57. https://doi.org/10.1002/syn.10154

Jackson AL, Linsley PS (2004) Noise amidst the silence: off-target effects of siRNAs? Trends Genet 20:521-524. https://doi.org/10. 1016/j.tig.2004.08.006

Jackson AL, Linsley PS (2010) Recognizing and avoiding siRNA offtarget effects for target identification and therapeutic application. Nat Rev Drug Discov 9:57-67. https://doi.org/10.1038/nrd3010

Jackson AL, Burchard J, Leake D et al (2006) Position-specific chemical modification of siRNAs reduces "off-target" transcript silencing. RNA 12:1197-1205. https://doi.org/10.1261/rna.30706

John GR, Lee SC, Song X et al (2005) IL-1-regulated responses in astrocytes: relevance to injury and recovery. Glia 49:161-176. https://doi.org/10.1002/glia.20109

Jooss K, Chirmule N (2003) Immunity to adenovirus and adeno-associated viral vectors: implications for gene therapy. Gene Ther 10:955-963. https://doi.org/10.1038/sj.gt.3302037

Kaidi A, Qualtrough D, Williams AC, Paraskeva C (2006) Direct transcriptional up-regulation of cyclooxygenase-2 by hypoxiainducible factor (HIF)-1 promotes colorectal tumor cell survival and enhances HIF-1 transcriptional activity during hypoxia. Cancer Res 66:6683-6691. https://doi.org/10.1158/0008-5472. CAN-06-0425

Kim S-S, Ye C, Kumar P et al (2010) Targeted delivery of siRNA to macrophages for anti-inflammatory treatment. Mol Ther 18:9931001. https://doi.org/10.1038/mt.2010.27

Koyama R, Ikegaya Y (2005) To BDNF or not to BDNF: that is the epileptic hippocampus. Neuroscientist 11:282-287. https://doi. org/10.1177/1073858405278266

Krueger JM, Fang J, Taishi P et al (1998) Sleep. A physiologic role for IL-1 beta and TNF-alpha. Ann N Y Acad Sci 856:148-159. https://doi.org/10.1111/j.1749-6632.1998.tb08323.x

Kumar P, Wu H, McBride JL et al (2007) Transvascular delivery of small interfering RNA to the central nervous system. Nature 448:39-43. https://doi.org/10.1038/nature05901

Li R, Ma L, Huang H et al (2017) Altered Expression of CXCL13 and CXCR5 in intractable temporal lobe epilepsy patients and pilocarpine-induced epileptic rats. Neurochem Res 42:526-540. https://doi.org/10.1007/s11064-016-2102-y

Liu X, Quan N (2018) Microglia and CNS interleukin-1: beyond immunological concepts. Front Neurol 9:8. https://doi.org/10.3389/ fneur.2018.00008

Livak KJ, Schmittgen TD (2001) Analysis of relative gene expression data using real-time quantitative PCR and the 2(-Delta Delta C(T)) method. Methods 25:402-408. https://doi.org/10.1006/ meth.2001.1262 
Lowenstein PR, Castro MG (2003) Inflammation and adaptive immune responses to adenoviral vectors injected into the brain: peculiarities, mechanisms, and consequences. Gene Ther 10:946-954. https://doi.org/10.1038/sj.gt.3302048

Malheiros JM, Persike DS, de Castro LUC et al (2014) Reduced hippocampal manganese-enhanced MRI (MEMRI) signal during pilocarpine-induced status epilepticus: edema or apoptosis? Epilepsy Res 108:644-652. https://doi.org/10.1016/j.eplepsyres.2014. 02.007

Manieri NA, Drylewicz MR, Miyoshi H, Stappenbeck TS (2012) Igf $2 b p 1$ is required for full induction of Ptgs 2 mRNA in colonic mesenchymal stem cells in mice. Gastroenterology 143:110-121. e10. https://doi.org/10.1053/j.gastro.2012.03.037

Marchesini RB (2011) Análise de genes envolvidos no modelo de epilepsia de lobo temporal induzido pela pilocarpina. Dissertation, University of Campinas. http://repositorio.unicamp.br/jspui/handle/REPOSIP/309730

Marchi N, Angelov L, Masaryk T et al (2007) Seizure-promoting effect of blood-brain barrier disruption. Epilepsia 48:732-742. https:// doi.org/10.1111/j.1528-1167.2007.00988.x

Matousek SB, Hein AM, Shaftel SS et al (2010) Cyclooxygenase-1 mediates prostaglandin $\mathrm{E}(2)$ elevation and contextual memory impairment in a model of sustained hippocampal interleukin-1beta expression. J Neurochem 114:247-258. https://doi.org/10.1111/j. 1471-4159.2010.06759.x

Mattson RH (1994) Current challenges in the treatment of epilepsy. Neurology 44:S4-S9 (discussion S31-32)

Mattson MP, Goodman Y, Luo H et al (1997) Activation of NF-kappaB protects hippocampal neurons against oxidative stress-induced apoptosis: evidence for induction of manganese superoxide dismutase and suppression of peroxynitrite production and protein tyrosine nitration. J Neurosci Res 49:681-697. https://doi.org/10.1002/(SICI) 1097-4547(19970915)49:6\%3c681::AID-JNR3\%3e3.0.CO;2-3

Mazzuferi M, Kumar G, Rospo C, Kaminski RM (2012) Rapid epileptogenesis in the mouse pilocarpine model: video-EEG, pharmacokinetic and histopathological characterization. Exp Neurol 238:156-167. https://doi.org/10.1016/j.expneurol.2012.08.022

Meini A, Benocci A, Frosini M et al (2000) Nitric oxide modulation of interleukin-1[beta]-evoked intracellular $\mathrm{Ca} 2+$ release in human astrocytoma U-373 MG cells and brain striatal slices. J Neurosci 20:8980-8986

Moore AH, Wu M, Shaftel SS et al (2009) Sustained expression of interleukin-1beta in mouse hippocampus impairs spatial memory. Neuroscience 164:1484-1495. https://doi.org/10.1016/j.neuro science.2009.08.073

Nairismägi J, Gröhn OHJ, Kettunen MI et al (2004) Progression of brain damage after status epilepticus and its association with epileptogenesis: a quantitative MRI study in a rat model of temporal lobe epilepsy. Epilepsia 45:1024-1034. https://doi.org/10.1111/j. 0013-9580.2004.08904.x

Ong B, Bergin P, Heffernan T, Stuckey S (2009) Transient seizurerelated MRI abnormalities. J Neuroimaging 19:301-310. https:// doi.org/10.1111/j.1552-6569.2008.00352.x

Panegyres PK, Hughes J (1998) The neuroprotective effects of the recombinant interleukin-1 receptor antagonist rhIL-1 ra after excitotoxic stimulation with kainic acid and its relationship to the amyloid precursor protein gene. J Neurol Sci 154:123-132. https:// doi.org/10.1016/s0022-510x(97)00214-1

Papoti D, Vidoto ELG, Martins MJ, Tannús A (2010) Effects of crossing saddle coil conductors: electric length $\mathrm{X}$ mutual inductance. Concepts Magn Reson B 37B:193-201

Pardridge WM (2007) Brain drug development and brain drug targeting. Pharm Res 24:1729-1732. https://doi.org/10.1007/ s11095-007-9387-0

Pascoal VAB (2010) O papel da interleucina -1 beta na fase aguda do modelo de epilepsia do lobo temporal induzido pela Pilocarpina.
Dissertation, University of Campinas. http://repositorio.unicamp. br/jspui/handle/REPOSIP/309738

Paxinos G, Watson C (2013) The rat brain in stereotaxic coordinates, 7th edn. Academic Press, London

Pearson JN, Schulz KM, Patel M (2014) Specific alterations in the performance of learning and memory tasks in models of chemoconvulsant-induced status epilepticus. Epilepsy Res 108:1032-1040. https://doi.org/10.1016/j.eplepsyres.2014.04.003

Pereira TC, Bittencourt VDP, Secolin R et al (2007) Strand Analysis, a free online program for the computational identification of the best RNA interference (RNAi) targets based on Gibbs free energy. Genet Mol Biol 30:1206-1208. https://doi.org/10.1590/ S1415-47572007000600030

Prior MJW, Brown AM, Mavroudis G et al (2004) MRI characterisation of a novel rat model of focal astrocyte loss. MAGMA 17:125-132. https://doi.org/10.1007/s10334-004-0065-5

Ravizza T, Gagliardi B, Noé F et al (2008) Innate and adaptive immunity during epileptogenesis and spontaneous seizures: evidence from experimental models and human temporal lobe epilepsy. Neurobiol Dis 29:142-160. https://doi.org/10.1016/j.nbd.2007. 08.012

Raza M, Pal S, Rafiq A, DeLorenzo RJ (2001) Long-term alteration of calcium homeostatic mechanisms in the pilocarpine model of temporal lobe epilepsy. Brain Res 903:1-12. https://doi.org/10. 1016/s0006-8993(01)02127-8

Rijkers K, Majoie HJ, Hoogland G et al (2009) The role of interleukin-1 in seizures and epilepsy: a critical review. Exp Neurol 216:258-271. https://doi.org/10.1016/j.expneurol.2008.12.014

Sander JW (1993) Some aspects of prognosis in the epilepsies: a review. Epilepsia 34:1007-1016. https://doi.org/10.1111/j.15281157.1993.tb02126.x

Sayyah M, Beheshti S, Shokrgozar MA et al (2005) Antiepileptogenic and anticonvulsant activity of interleukin-1 beta in amygdalakindled rats. Exp Neurol 191:145-153. https://doi.org/10.1016/j. expneurol.2004.08.032

Scharfman HE, Pierce JP (2012) New insights into the role of hilar ectopic granule cells in the dentate gyrus based on quantitative anatomic analysis and three-dimensional reconstruction. Epilepsia 53(Suppl 1):109-115. https://doi.org/10.1111/j.1528-1167.2012.03480.x

Schlachetzki F, Zhang Y, Boado RJ, Pardridge WM (2004) Gene therapy of the brain: the trans-vascular approach. Neurology 62:12751281. https://doi.org/10.1212/01.wnl.0000120551.38463.d9

Schneider H, Pitossi F, Balschun D et al (1998) A neuromodulatory role of interleukin-1beta in the hippocampus. Proc Natl Acad Sci USA 95:7778-7783. https://doi.org/10.1073/pnas.95.13.7778

Smolders I, Khan GM, Manil J et al (1997) NMDA receptor-mediated pilocarpine-induced seizures: characterization in freely moving rats by microdialysis. Br J Pharmacol 121:1171-1179. https://doi. org/10.1038/sj.bjp.0701231

Soloff MS, Izban MG, Cook DL et al (2006) Interleukin-1-induced NFkappaB recruitment to the oxytocin receptor gene inhibits RNA polymerase II-promoter interactions in cultured human myometrial cells. Mol Hum Reprod 12:619-624. https://doi.org/10.1093/ molehr/gal067

Šutulović N, Grubač Ž, Šuvakov S et al (2019) Chronic prostatitis/ chronic pelvic pain syndrome increases susceptibility to seizures in rats and alters brain levels of IL-1 $\beta$ and IL-6. Epilepsy Res 153:19-27. https://doi.org/10.1016/j.eplepsyres.2019.03.014

Taglialatela G, Robinson R, Perez-Polo JR (1997) Inhibition of nuclear factor kappa B (NFkappaB) activity induces nerve growth factorresistant apoptosis in PC12 cells. J Neurosci Res 47:155-162

Tanic N, Perovic M, Mladenovic A et al (2007) Effects of aging, dietary restriction and glucocorticoid treatment on housekeeping gene expression in rat cortex and hippocampus-evaluation by real time RT-PCR. J Mol Neurosci 32:38-46. https://doi.org/10.1007/ s12031-007-0006-7 
Tian D-S, Peng J, Murugan M et al (2017) Chemokine CCL2-CCR2 signaling induces neuronal cell death via STAT3 activation and IL-1 $\beta$ production after status epilepticus. J Neurosci 37:78787892. https://doi.org/10.1523/JNEUROSCI.0315-17.2017

Tschuch C, Schulz A, Pscherer A et al (2008) Off-target effects of siRNA specific for GFP. BMC Mol Biol 9:60. https://doi.org/10. 1186/1471-2199-9-60

Turski WA, Cavalheiro EA, Bortolotto ZA, Mello LM, Schwarz M, Turski L (1984) Seizures produced by pilocarpine in mice: a behavioral, electroencephalographic and morphological analysis. Brain Res 321(2):237-253. https://doi.org/10.1016/00068993(84)90177-x

van Eijsden P, Otte WM, van der Hel WS et al (2011) In vivo diffusion tensor imaging and ex vivo histologic characterization of white matter pathology in a post-status epilepticus model of temporal lobe epilepsy. Epilepsia 52:841-845. https://doi.org/10.1111/j. 1528-1167.2011.02991.x

Vezzani A, Conti M, De Luigi A et al (1999) Interleukin-1beta immunoreactivity and microglia are enhanced in the rat hippocampus by focal kainate application: functional evidence for enhancement of electrographic seizures. J Neurosci 19:5054-5065

Vezzani A, Moneta D, Conti M et al (2000) Powerful anticonvulsant action of IL-1 receptor antagonist on intracerebral injection and astrocytic overexpression in mice. Proc Natl Acad Sci USA 97:11534-11539. https://doi.org/10.1073/pnas.190206797

Vezzani A, Moneta D, Richichi C et al (2002) Functional role of inflammatory cytokines and antiinflammatory molecules in seizures and epileptogenesis. Epilepsia 43(Suppl 5):30-35. https:// doi.org/10.1046/j.1528-1157.43.s.5.14.x

Vezzani A, Bartfai T, Bianchi M et al (2011) Therapeutic potential of new antiinflammatory drugs. Epilepsia 52(Suppl 8):67-69. https:// doi.org/10.1111/j.1528-1167.2011.03242.x
Viviani B, Bartesaghi S, Gardoni F et al (2003) Interleukin-1beta enhances NMDA receptor-mediated intracellular calcium increase through activation of the Src family of kinases. J Neurosci 23:8692-8700

Voutsinos-Porche B, Koning E, Kaplan H et al (2004) Temporal patterns of the cerebral inflammatory response in the rat lithiumpilocarpine model of temporal lobe epilepsy. Neurobiol Dis 17:385-402. https://doi.org/10.1016/j.nbd.2004.07.023

Wen A, Wang J, Feng K et al (2006) Effects of haplotypes in the interleukin 1beta promoter on lipopolysaccharide-induced interleukin 1beta expression. Shock 26:25-30. https://doi.org/10.1097/01.shk. 0000223125.56888.c7

Yi P-L, Tsai C-H, Lin J-G et al (2004) Kindling stimuli delivered at different times in the sleep-wake cycle. Sleep 27:203-212. https:// doi.org/10.1093/sleep/27.2.203

Yuhas Y, Shulman L, Weizman A et al (1999) Involvement of tumor necrosis factor alpha and interleukin-1beta in enhancement of pentylenetetrazole-induced seizures caused by Shigella dysenteriae. Infect Immun 67:1455-1460. https://doi.org/10.1128/IAI. 67.3.1455-1460.1999

Zahedi K, Seldin MF, Rits M et al (1991) Mouse IL-1 receptor antagonist protein. Molecular characterization, gene mapping, and expression of mRNA in vitro and in vivo. J Immunol 146:4228-4233

Zhu G, Okada M, Yoshida S et al (2006) Effects of interleukin-1beta on hippocampal glutamate and GABA releases associated with $\mathrm{Ca} 2+$-induced $\mathrm{Ca} 2+$ releasing systems. Epilepsy Res 71:107-116. https://doi.org/10.1016/j.eplepsyres.2006.05.017

Publisher's Note Springer Nature remains neutral with regard to jurisdictional claims in published maps and institutional affiliations.

\section{Authors and Affiliations}

\section{D. B. Pascoal ${ }^{1,2}$ - R. B. Marchesini ${ }^{1}$ - M. C. P. Athié ${ }^{1}$ A. H. B. Matos ${ }^{1}$ - F. F. Conte ${ }^{1} \cdot$ T. C. Pereira ${ }^{1,3} \cdot$ R. Secolin ${ }^{1,2}$.

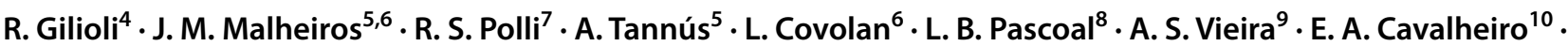 F. Cendes ${ }^{11} \cdot$ I. Lopes-Cendes ${ }^{1}$ (ID}

1 Department of Translational Medicine, School of Medical Sciences, University of Campinas (UNICAMP), and the Brazilian Institute of Neuroscience and Neurotechnology (BRAINN), Tessália Vieira de Camargo, 126, Cidade Universitária "Zeferino Vaz", Campinas, SP 13083-887, Brazil

2 Department of Basic Science, Fluminense Federal University, Nova Friburgo, RJ, Brazil

3 Department of Biology, Faculty of Philosophy, Sciences and Letters at Ribeirao Preto, University of Sao Paulo (USP), Ribeirao Preto, SP, Brazil

4 Multidisciplinary Centre for Biological Investigation (CEMIB), University of Campinas (UNICAMP), Campinas, SP, Brazil

5 Centro de Imagens e Espectroscopia por Ressonancia Magnetica (CIERMag), Institute of Physics, University of Sao Paulo (USP), Sao Carlos, SP, Brazil
6 Department of Physiology, Federal University of Sao Paulo (UNIFESP), Sao Paulo, SP, Brazil

7 Institute of Science and Technology, Federal University of São Paulo, São José dos Campos, SP, Brazil

8 Laboratory of Cell Signaling, School of Medical Sciences, University of Campinas - (UNICAMP), Campinas, SP, Brazil

9 Department of Structural and Functional Biology, Institute of Biology, University of Campinas - (UNICAMP), Campinas, SP, Brazil

10 Department of Neurology and Neurosurgery, Federal University of Sao Paulo, (UNIFESP), Sao Paulo, SP, Brazil

11 Department of Neurology, School of Medical Sciences, University of Campinas - (UNICAMP); and the Brazilian Institute of Neuroscience and Neurotechnology (BRAINN), Campinas, SP, Brazil 